\title{
The Awareness and Implementation of Foodbank Program in Malaysian University
}

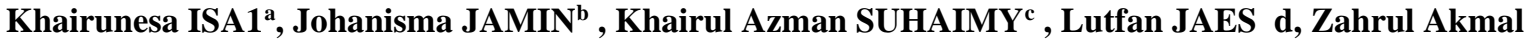 \\ DAMIN $^{e}$, Muhaymin Hakim ABDULLAH ${ }^{f}$, Nor Shela SALEH g, and Sarala Thulasi PALPANADAN ${ }^{\text {h }}$ \\ A \\ Social Impact Focus Group, Centre for General Studies and Co-Curricular, \\ Universiti Tun Hussein Onn Malaysia, 86400 Parit Raja, Batu Pahat, Johor \\ ${ }^{\mathbf{b}}$ Faculty of Technical and Vocational Education, \\ Universiti Tun Hussein Onn Malaysia, 86400 Parit Raja, Batu Pahat, Johor \\ 'Social Impact Focus Group, Centre for General Studies and Co-Curricular, \\ Universiti Tun Hussein Onn Malaysia, 86400 Parit Raja, Batu Pahat, Johor \\ dSocial Impact Focus Group, Centre for General Studies and Co-Curricular, \\ Universiti Tun Hussein Onn Malaysia, 86400 Parit Raja, Batu Pahat, Johor \\ $\mathbf{E}$ Social Impact Focus Group, Centre for General Studies and Co-Curricular, \\ Universiti Tun Hussein Onn Malaysia, 86400 Parit Raja, Batu Pahat, Johor \\ fSocial Impact Focus Group, Centre for General Studies and Co-Curricular, \\ Universiti Tun Hussein Onn Malaysia, 86400 Parit Raja, Batu Pahat, Johor \\ gSocial Impact Focus Group, Centre for General Studies and Co-Curricular, \\ Universiti Tun Hussein Onn Malaysia, 86400 Parit Raja, Batu Pahat, Johor \\ ${ }^{\text {h}}$ Center for Language Studies, Universiti Tun Hussein Onn Malaysia, 86400 Parit Raja, Batu Pahat, Johor
}

Article History: Received: 11 January 2021; Accepted: 27 February 2021; Published online: 5 April 2021

\begin{abstract}
The Foodbank Malaysia Foundation (YFBM) is a foundation that has been established to introduce as one of the initiative to help the underprivileged to access food which indirectly reduces the issue of food waste among Malaysians. Foodbank Malaysia Program has been introduced as a program to help anyone to make sure they can eat per day without any problem and this includes university students in Malaysia. Indeed, it is very important to distribute the food from the foodbank program to those university students who are in need to make sure all the underprivileged students get help from the university authorities. Therefore, the purpose of this paper is to measure the level of awareness and to analyze the implementation of foodbank program among students. A total of 350 students were selected using simple random sampling method. The data were analyzed descriptively via Statistical Package for the Social Science Version 25.0 (SPSS version 25.0). Using descriptive statistics, the finding indicated that the university students had a high level of awareness about the foodbank program with a mean score value 3.61 and the result for the implementation of foodbank program among university students showed a high level with a mean score 3.99. Based on the Linear Regression Analysis results, the overall findings indicated that students' foodbank awareness were closely related to the implementation of foodbank program in university with $\beta=0.732$.
\end{abstract}

Keywords: Foodbank, Students Awareness, University Students, Higher Education.

\section{Introduction}

The Ministry of Domestic Trade and Consumer Affairs (KPDNHEP) has launched a Malaysia Foodbank Program that highlights the impact of rising costs on Malaysians. The Malaysia Foodbank Program also focuses on reducing food waste among Malaysians. Even former Prime Minister, Tun Dr Mahathir Mohamad (KPDNHEP, 2019) said the effort was a voluntary work that required huge financial allocations from the government. Tun made this statement in 2019 when these foodbank program had just been started to make sure other people know about the program.

The initiative also requires the cooperation of the private and non-governmental organizations (NGOs) to jointly assist the government in addressing food waste issues. This Malaysia Foodbank Program is very helpful in reducing the cost of living for the underprivileged and those in the B40 group in Malaysia. The former deputy prime minister, Dr Wan Azizah said in Sinar Harian (2019), these non-governmental organizations (NGOs) would jointly collect food from the participating shopping centers and distribute the food once a week to the underprivileged group B40 which is the target group of the Malaysia Foodbank Program. The shopping centres which participate in this Malaysia Foodbank Program include Tesco, Econsave, The Store, NSK, and SEGI shopping mall.

Effie et. al., (2019), stated in their study in the field of hospitality and food service that three-quarters of the food in the world was wasted and almost half of it was the type of food waste that could be reused to make something else or given to those in need. This food waste situation can be avoided by using some good strategies and systematic management. Many countries are trying to make policies regarding this matter and still improvising until now. In this regard, the Malaysia Foodbank Program is one of the measures of the Malaysian government to manage waste surplus at these food service centers for example from shopping mall, school, household, or food factory that need to dispose any food which have almost reached the expiry date. Besides, another measure of the 
government by using Malaysia Foodbank Program is by collaborating with the university management and NGOs that have expertise in this matter to distribute these food waste to those in need.

The Foodbank Malaysia Foundation (YFBM) is a foundation that has been established as an initiative to help the underprivileged to access food which indirectly reduces the issue of food waste among Malaysians while addressing the issue of rising cost of living in Malaysia, especially in Sabah and Sarawak (Sinar Harian, 2019). In addition, KPDNHEP has also expanded the Malaysia Foodbank Program to public university campuses for students in need of food (Suhaila, 2019). The students involved are those underprivilaged group in the B40 family and registered with their respective university registrars. In the United Nation, in 2015, food waste was one of the most recognized and at the highest levels of disquietude and concern at the global level. Most of the surplus food products from schools and child care centers (Silvennoinen et al., 2012) can also help to make the Malaysia Foodbank Program successful. This excess food can be stored in a variety of ways according to the type of needs of the food to reduce wastage (Juha, 2014), and can be distributed to university students who are in need.

\section{Methodology}

This quantitative research involved 350 randomly selected students from a university in Malaysia. The respondents were the students in their diploma, degree, master and PHD programs. Without any coercion from others, students could answer the questionnaire as long as they were the students of the university. The questionnaire was distributed by using google online form with three different parts that included respondents' demography, the level of foodbank awareness and the implementation of foodbank among university students. The questionnaire was administered to measure the students' level of foodbank awareness in university and at the same time the objective of this study was to analyze the implementation of foodbank program in the university. The Cronbach Alpha obtained from this research was 0.936 which showed a very good internal reliability for this study. All the data was descriptively analyzed and interpreted using Statistical Package for the Social Science Version 25 (SPSS Ver.25).

\section{Findings and Discussion}

\subsection{Demography Profile of the Respondents}

A demographic backgrounds including gender, age and ethnicity of the respondents are shown in Table 1. A total of 350 university students were involved in this study where both gender; male and female were involved in this survey of foodbank users. More than half of the participants were females (64.9\%) involving 227 respondents and the remaining 123 respondents $(35.1 \%)$ were male students. This analysis was supported by Julia Depa et. al (2018) in their research which stated that more than half of the participants in their foodbank users were females. In addition, Shanthi Johnson and Nicki Hawkins (2010) agreed in their research that the majority of the foodbank users were women in poverty and these basic food needs can help the poor women who worked nonstop improve their daily life a little. In this study, all the respondents were university students who answered the questionnaire based on their range of age.

The majority of the respondents (134 university students) were in the range of 20-24 years old which was $38.3 \%$ of the respondents. Followed by the range of 25-29 years old which with 116 respondents (33.1\%). 64 respondents $(18.3 \%$ ) representing the respondents who were 30 years old and above while the lowest range of age which answer the questionnaire was 19 years old and below (36 respondents, 10.3\%). Based on Table 1, from the questionnaire of ethnicity, more than half of the participants were Malays (around 247 respondents) and $70.6 \%$ of the whole participants. Chinese and Indian ethnicities were represented by 34 respondents (9.7\%) and 24 respondents $(6.9 \%)$ respectively. While the others represented around 45 respondents (12.9\%). The 'others' ethnicity included the native people around Malaysia including the peninsular, Sabah and Sarawak. As indicated by Madeleine Power et. al., (2017) the data from a multiethnic can help to better understand the constitutes community of food aid.

Table 1 Demography Profile of the Respondents $(n=350)$

FREQUENCY (n)

PERCENTAGE \%

\begin{tabular}{r|cc}
\hline GENDER & & 35.1 \\
Male & 123 & 64.9 \\
Female & 227 & 10.3 \\
AGE & & 38.3 \\
$>19$ Years & 36 & 33.1 \\
$20-24$ Years & 134 & 3 \\
\hline
\end{tabular}




\begin{tabular}{r|cc}
$<30$ Years & 64 & 18.3 \\
& & \\
& & \\
& & \\
ethnicity & 247 & 70.6 \\
malay & 34 & 9.7 \\
chinese & 24 & 6.9 \\
indian & 45 & 12.9 \\
others & &
\end{tabular}

\subsection{The Awareness of Foodbank among University Students}

Table 2 shows the data that had been required from the questionnaire about the awareness of the university students regarding foodbank program in university. The analysis details showes that majority of the students in the university have an awareness regarding foodbank program in their universities. All the items from B1 till B10 obtained high mean score values between the range of 3.10 and above. According to the data below, 'I'm aware of the need for foodbank among university students' in item B7 was the item with the highest mean score value 4.04 with standard deviation 0.90. According to Jamil (2002), the interpretation for mean score used for statistical descriptive analysis shows that the range between 3.67 and above is in the highest range. This means the highest mean score value in this studies is in item B7. From this result, it can be concluded that the majority of the university students have an awareness regarding foodbank program in their university. This study coincides with Rebecca Lucas' (2018) findings that the importance of the foodbank awareness need to be informed to those in need. There are a lot of university students who have issues within their family regarding the lack of essential living expenses in daily life.

Item B10 which is 'I am aware that IPTA \& IPTS in Malaysia implementing a foodbank program in their university' achieved the high mean score value 3.92 and the standard deviation 0.98. Tomio Kobayashi et. al., (2018) in their study revealed that many countries campaign their foodbank program under the government social welfare with the help of non-profit organizations (NGOs) and at the same time defined as 'informal care'. It is the same with the university management when they link with KDNHEP (2019), which is responsible in giving a foodbank welfare to those University students who are in need. In item B8 'I've seen advertisement on foodbanks on social media', the score mean value was 3.82 and the standard deviation 1.10 which was within the high range score mean. This shows most of the university students had seen the advertisement regarding foodbank via Malaysian advertisement or from oversea.

'I have no problem providing my personal information to sign up for a foodbank program' in item B6 with score mean value 3.79 and the standard deviation 0.96 which highlighted that most of the university students could cooperate if there was need for them to help other people or other organizations to expand their roles to help people who needed nutrition and health (Marianna S. Wetherill, Kayla C. White \& Hilary Seligman, 2019). Item B1, 'I know about the implementation of the foodbank' had the score mean value 3.78 and the standard deviation 0.99 . This data showed that the information was wide, not specifically within the university but it more of the country, Malaysia. Most university students knew that Malaysia started implementing this foodbank program when the former Prime Minister, Tun Dr Mahathir Mohamad (KPDNHEP, 2019) said in his speech regarding the matter of food waste which really concerned our nation.

Table 2 shows that item B5 'I believe I can contribute to the sustainability of the foodbank program' achieved the score mean value 3.76 and the standard deviation 0.95. While 'My friends around me were aware of the existence of the foodbank program' in item B9 achieved high mean score value 3.42 and the standard deviation was 1.03. The dat showed that the people around the respondents do not necessarily know about the foodbank program. A big part of them had the awareness about foodbank in university but not all of them although it was supposed to be a general knowledge. Although this program had been implemented since 2019, and had been introduced since 2018 in Malaysia by KDNHEP (2019), but only a part of the people know about the foodbank program especially the foodbank program in university.

'I will organize a campaign on foodbanks if I have an opportunity.' in item B4 with a mean score value 3.30 and standard deviation 1.13 was in high range. This result showed that most of the university students wanted to participate in the foodbank program if they had an opportunity. This issue is supported by Chantelle Bazerghi, Fiona \& Matthew Dunn (2017), in the study that mentioned foodbank has an important role to help people in need. 
It can also provide immediate solutions to food deprivation especially to university students who do not have any money to buy food. Item B2 which was 'I had attended seminars / workshops / programs on foodbank' had a moderate mean score 2.825 and the standard deviation 1.356. Most of the respondents answered that they had attended seminars, workshops or programs about foodbank at least once. As supported by E. Prayogo et. al., (2017), most of the university students refused to attend any program about foodbank and the common reasons for the refusal were such as busy and not interested. 'I am one of the membership who involved in foodbank operations' in item B3 showed the lowest range for the mean score value of 3.10 with the standard deviation of 1.29. As mentioned by E. Prayogo et. al., (2017), they are too busy doing other things that make them think that they do not need to participate in any foodbank operations. At the same time they think they already know about the program without having to attend as they have other priorities.

Table 2 Awareness of Foodbank among Students in University $(n=350)$

\begin{tabular}{|c|c|c|c|}
\hline BIL & ITEM & MEAN & STD. DEVIATION \\
\hline B1 & $\begin{array}{l}\text { I know about the implementation of } \\
\text { the foodbank. }\end{array}$ & 3.78 & 0.99 \\
\hline B2 & $\begin{array}{l}\text { I had attended seminars / workshops / } \\
\text { programs on foodbank. }\end{array}$ & 3.17 & 1.35 \\
\hline B3 & $\begin{array}{l}\text { I am one of the membership who } \\
\text { involved in foodbank operations. }\end{array}$ & 3.10 & 1.29 \\
\hline B4 & $\begin{array}{l}\text { I will organize a campaign on } \\
\text { foodbanks if I have an opportunity. }\end{array}$ & 3.30 & 1.13 \\
\hline B5 & $\begin{array}{l}\text { I believe I can contribute to the } \\
\text { sustainability of the foodbank program. }\end{array}$ & 3.76 & 0.95 \\
\hline B6 & $\begin{array}{l}\text { I have no problem providing my } \\
\text { personal information to sign up for a } \\
\text { foodbank program. }\end{array}$ & 3.79 & 0.96 \\
\hline B7 & $\begin{array}{l}\text { I'm aware of the need for foodbank } \\
\text { among university students. }\end{array}$ & 4.04 & 0.90 \\
\hline B8 & $\begin{array}{l}\text { I've seen advertisement on foodbanks } \\
\text { on social media. }\end{array}$ & 3.82 & 1.10 \\
\hline B9 & $\begin{array}{l}\text { My friends around me were aware of } \\
\text { the existence of the foodbank program }\end{array}$ & 3.42 & 1.03 \\
\hline B10 & $\begin{array}{l}\text { I am aware that IPTA \& IPTS in } \\
\text { Malaysia implementing a foodbank } \\
\text { program in their university. }\end{array}$ & 3.92 & 0.98 \\
\hline
\end{tabular}

\subsection{Implementation of Foodbank among Students in University}

Table 3 shows the details of the variable about the implementation of foodbank among students in university. The table reveals that item $\mathrm{C} 14$, 'The food bank program provides awareness to manage the excess food to the right channels' had the highest mean score value 4.13 and the standard deviation 0.86 . This item was the highest among the others as shown in Table 3. It should be noted that university students know the right objective of the foodbank created in many countries. The aim for foodbank is not just to help people in need but also to manage the food waste that had been a concern of many countries including Malaysia. Stephen F Hamilton and Timothy $\mathbf{J}$ Richards (2019) stated that food waste keep on rising among household and shopping centre. When foodbank was introduced, automatically these problems can be solved gradually with more alternatives without wasting any food. Item C13 'Through the food bank program, I am more than ready to share food with my less fortunate friends' had 
the second highest with score mean value 4.10 and the standard deviation 0.92 . Besides, majority of the university students can now be ready to share their excess food which they do not want to eat or the food that they bought extra through foodbank program. Without our knowledge, there are actually many people who only eat once a day. Rachel Loopstar (2018) stated that many of the unfortunate people keep on experiencing cutting their meals, skipping their meals, getting unbalanced meals or feeling hungry but unable to eat due to the lack of money to buy food. So when students are aware of these problems, they can help these people by sharing what they have.

Item C15 'I saw the foodbank program introduced in Malaysia received a lot of response from various parties' had high mean score value 4.02 and the standard deviation 0.93. As stated before, foodbank program been introduced before and from this mean value means most of the university students know that the foodbank program had been implemented since 2019 as mentioned by the former Prime Minister Tun Dr Mahathir Mohamad (KPDNHEP, 2019). Thus, the government should spare a huge financial effort to help university students in need by joinning with others parties such as non-profit government (NGOs). The government cannot implement this program around Malaysia alone because the lack of labor force to manage. Besides, there is no one who can take this voluntary job except the volunteers in NGOs. Item C12 'The food bank program helped reduce the cost of living as a student at my university' had the score mean value 3.96 and the standard deviation 0.92 . Most students get help from foodbank because of their families' low income, and those who registered as the receivers of the foodbank program agreed that this program can help them to cut cost of their living expense especially in their food cost (Valerie Tarasuk, 2014). The last item was item C11 'I benefited from the food bank program introduced at my place' with the score mean value 3.76 and the standard deviation 1.00 . Not that many university students agreed with the item because most of them were still studiying and only some of them were doing part time job where they can see how this program can help them within their job range.

Table 3 Implementation of Foodbank among Students in University

$\begin{array}{llll}\text { BIL ITEM MEAN STD. DEVIATION } & \end{array}$

\begin{tabular}{|c|c|c|c|}
\hline C11 & $\begin{array}{l}\text { I benefited from the food bank } \\
\text { program introduced at my place. }\end{array}$ & 3.76 & 1.00 \\
\hline C12 & $\begin{array}{l}\text { The food bank program helped reduce } \\
\text { the cost of living as a student at my } \\
\text { university. }\end{array}$ & 3.96 & 0.92 \\
\hline C13 & $\begin{array}{l}\text { Through the food bank program, I am } \\
\text { more than ready to share food with my } \\
\text { less fortunate friends. }\end{array}$ & 4.10 & 0.92 \\
\hline C14 & $\begin{array}{l}\text { The food bank program provides } \\
\text { awareness to manage the excess food to } \\
\text { the right channels }\end{array}$ & 4.13 & 0.86 \\
\hline C15 & $\begin{array}{l}\text { I saw the foodbank program } \\
\text { introduced in Malaysia received a lot of } \\
\text { response from various parties }\end{array}$ & 4.02 & 0.93 \\
\hline
\end{tabular}

3.4 Cronbach's Alpha Value \& Coefficient of Dependent Variable

Table 4 Cronbach's Alpha Value

\begin{tabular}{r|c}
\hline Variable & Cronbach's Alpha Value \\
\hline Awareness & 0.907 \\
\hline Implementation & 0.914 \\
\hline
\end{tabular}


Table 5 Coefficient of Dependent Variable

\begin{tabular}{lccccc}
\hline \multirow{2}{*}{ Model } & \multicolumn{2}{c}{$\begin{array}{c}\text { Standardized } \\
\text { Unstandardized } \\
\text { Coefficients }\end{array}$} & Coefficients & & \\
& B & $\begin{array}{c}\text { Std. } \\
\text { Error }\end{array}$ & Beta & & Sig. \\
\cline { 2 - 5 } & 1.339 & .136 & & & \\
\hline (Constant) & .736 & .037 & .732 & 20.056 & .000 \\
\hline Awareness & & & & & \\
\hline
\end{tabular}

\section{a. Dependent Variables: Implementation}

Table 4 shows that the implementation of foodbank program factor has a high Alpha Cronbach's alpha value which is 0.914 followed by the awareness of foodbank program which is 0.907 . High reliability coefficient value indicates high instrument reliability. While Table 5 depicts the coefficient beta which is contributed by the awareness of foodbank program among university students $(\beta=0.732)$. This indicated that the awareness of foodbank program among university students were closely related to the implementation of foodbank program in the university. The variable of awareness of foodbank program made a significant contribution to the prediction of the dependent variable which was the implementation foodbank program in university, as the significant value for the variable was less than 0.05 .

\section{Conclusion}

The foodbank program in Malaysia had been introduced formally by our former Prome Minister. Since then, a variety of people can get the help from this program without any exception regarding their ethnicity, age, gender or even income. As long as there is someone who needs help, this program can help to provide food to help the person to survive in daily life. Based on the result, most of the university students seemed to have awareness about foodbank program in their surrounding and their own university. Even majority of them know that this foodbank program had been implemented in their university. Every university has its own management which links with every KDNHEP in their area. If there is any problem or question that the university students need to take note or find answers, they can directly contact the person in charge at the university and that person will directly get help from authorities in KPDNHEP to help resolve the problem. In conclusion, based on the finding of this study, it can be concluded that the awareness of the foodbank program among university students is significant with the implementation of foodbank program in university.

\section{References}

1. Chantelle Bazerghi, Fiona H McKay \& Matthew Dunn. 2017. The Role of Food Banks in Addressing Food Insecurity: A systematic review. Journal of Community Health. 12 October 2017..

2. Effie Papargyropoulou, Julia K. Steinberger, Nigel Wright, Rodrigo Lozano, Rory Padfield

3. and Zaini Ujang. 2019. Patterns and Causes of Food Waste in the Hospitalityand Food Service Sector: Food Waste Prevention Insights from Malaysia. Journal of Sustainability. Vol. 11, 6016.

4. E. Prayogo, A. Chater, S. Chapman, M. Barker, N. Rahmawati, T. Waterfall and G. Grimble. 2017. Who Uses Foodbanks And Why? Exploring The Impact Of Financial Strain And Adverse Life Events On Food Insecurity. Journal of Public Health. Vol. 40, No. 4, pp. 676-683

5. Juha-Matti Katajajuuri, Kirsi Silvennoinen, Hanna Hartikainen, Lotta Heikkila, Anu Reinikainen. 2014. Food Waste In The Finish Food Chain. Journal of Cleaner Production 73 (2014) 322e329.

6. Julia Depa, Fiona Gyngell, Annalena Müller, Laila Eleraky, Carolin Hilzendegen, Nanette StroebeleBenschop. 2018. Prevalence of food insecurity among food bank users in Germany and its association with population characteristics. Preventive Medicine Reports 9 (2018) 96-101.

7. KPDNHEP. 2019. Pelancaran Program Food Bank. Unit Komunikasi Korporat. Retrieved from https://www.kpdnhep.gov.my/kpdnkk/majlis-pelancaran-program-food-bank-malaysia/?lang=en

8. Madeleine Power, Bob Doherty, Neil Small, Simon Teasdale, And Kate E. Pickett. 2017. All in it Together? Community Food Aid in a Multi-Ethnic Context. Cambridge University Press 2017. Jnl Soc. Pol. (2017), 46, 3, 447-471

9. Marianna S. Wetherill, Kayla C. White \& Hilary Seligman (2019) Charitable food as prevention: Food bank leadership perspectives on food banks as agents in population health, Community Development, 50:1, 92-107, DOI: $10.1080 / 15575330.2019 .1570961$

10. Rachel Loopstra. 2018. Interventions to address household food insecurity in high-income countries. Proceedings of the Nutrition Society (2018), 77, 270-281 
11. Rebecca Lucas. 2018. A campaign to raise awareness of the importance of food banks and to encourage donations. Retrieved from https://thenorthernquota.org/campaigns/campaign-raise-awarenessimportance-food-banks-and-encourage-donations

12. Shanthi Johnson and Nicki Hawkins. 2010. Calcium Nutrition perceptions among Food Bank Users: A Canadian Case Study. International Electronic Journal of Health Education, 2010; 13:100-110

13. Silvennoinen, K., Katajajuuri, J.-M., Hartikainen, H., Jalkanen, L., Koivupuro, H.-K., Reinikainen, A., 2012. Food waste volume and composition in the Finnish Supply chain: special focus on food service sector. In: Fourth International Symposium on Energy from Biomass and Waste, Venice, Italy, 12e15 November 2012: Proceedings Venice 2012. Cisa Publisher, p. 14.

14. Sinar Harian. 2019. Food Bank Malaysia Manfaat 45,850 Anggota Isi Rumah. Retrieved from https://www.sinarharian.com.my/article/20958/BERITA/Nasional/Food-Bank-Malaysia-manfaat45850-anggota-isi-rumah.

15. Stephen F Hamilton and Timothy J Richards. 2019. Food Policy and Household Food Waste. American Journal of Agricultural Economics, Volume 101, Issue 2, March 2019, Pages 600-614

16. Suhaila Shahrul Anuar. 2019. Berita Harian: Foodbank Malaysia Diperluas Ke Universiti Awam. Retrieved from https://www.bharian.com.my/berita/nasional/2019/03/542372/foodbank-malaysiadiperluas-ke-universiti-awam

17. Tomio Kobayashi, Jagath Kularatne, Yutaka Taneichi and Nobuhide Aihara. 2018. Analysis of food bank implementation as formal care assistance in Korea. British Food Journal. Vol. 120 No. 1, 2018 pp. 182 195

18. United Nations. Transforming our world: The 2030 agenda for sustainable development. In Proceedings of the General Assembly 70 Session, New York, NY, USA, 25 September 2015.

19. Valerie Tarasuk, Naomi Dachner, Anne-Marie Hamelin, Aleck Ostry, Patricia Williams, Elietha Bosckei, Blake Poland and Kim Raine. 2014. A survey of food bank operations in five Canadian Cities. BMC Public Health 2014, 14:1234 